\title{
Lost in translation: Ireland and the Patten Report
}

\author{
VICKY CONWAY
}

\author{
Junior Lecturer in Law, School of Law, University of Limerick*
}

\begin{abstract}
$\underline{\text { Abstract }}$
Police accountability structures in the Republic of Ireland have recently undergone fundamental reform in response to international developments and domestic scandals. During the debates as to what shape new measures should take, numerous commentators called for implementation of the Patten Report. This article will evaluate the role which the Patten Report played in the reform debates. It will be argued that by interpreting that report as recommending a series of new mechanisms, rather than reflecting on the theoretical underpinnings, the value which it has for other jurisdictions has become lost in translation. By analysing the reforms which were introduced in Ireland from the theoretical framework in Patten, the deficiencies of the new system in the Republic will be highlighted. Through this case study, the potential value of the Patten Report for other jurisdictions, in providing a theoretically sound blueprint for accountability reform, will be elaborated.
\end{abstract}

\section{The problem of police accountability}

$T^{\text {he }}$ complexities of police accountability are well rehearsed elsewhere. ${ }^{1}$ Why 1 accountability is an issue, to whom should the police be accountable, and how accountability should be achieved, are questions which have been asked time and again across all jurisdictions. In a democratic state, where the people have ceded power to the government, there is an entitlement to hold the government and its various institutions to account for the use of that power. With a public police force, the concern centres on the powers which are afforded to the police in order to maintain public order and investigate crime, and in particular the discretionary nature of those powers. The potential for abuse is high, and the impact of abuse for individual citizens can involve serious breaches of their human rights. Accountability has had periods of topicality in most jurisdictions. ${ }^{2}$ It consumed media and political debates in the USA in the 1960s; Canada, Australia and the

* The author would like to thank Professor Dermot Walsh and Dr Barry Vaughan for their useful comments and suggestions on earlier drafts of this paper.

1 See, generally, G Marshall, "Police accountability revisited' in D Butler and A H Halsey (eds), Policy and Politics (Basingstoke: Macmillan, 1978); M Brogden, T Jefferson and S Walklate, Introducing Police Work (London: Harper Collins, 1988); T Jefferson and R Grimshaw, Controlling the Constable (London: Muller, 1984); R Reiner, The Politics of the Police (New York: St Martin's Press, 1985); P Scraton, The State of the Police (Dover, NH: Pluto Press, 1985); L Lustgarten, The Governance of the Police (London: Sweet \& Maxwell, 1986); P Day and R Klein, Accountabilities: Five Public Services (London: Tavistock, 1987).

2 R Reiner and S Spencer, Accountable Policing: Effectiveness, empowerment and equity (London: Institute for Public Policy Research, 1993) p. 74. 
UK in the $1980 \mathrm{~s} ;{ }^{3}$ transitional societies such as Northern Ireland and South Africa in the $1990 \mathrm{~s} ;{ }^{4}$ and in the last number of years it has reached heightened levels of discussion in Ireland. ${ }^{5}$ In most of these jurisdictions it arises as a result of a serious scandal, affecting the reaction as it has become politicised. ${ }^{6}$

And yet with universal agreement on the need to hold police to account, how this should be achieved is highly contested. At the heart of this debate is what is meant by the term accountability because, dependent on what accountability is intended to achieve, the mechanisms employed will differ substantially. ${ }^{7}$ Debates have centred on whether accountability entails making the police explain their actions, or more proactively, whether it actually involves some control of the force. ${ }^{8}$ Day and Klein have suggested that the term accountability can cover a range of meanings, including "answerability, responsiveness, openness, efficient estate management, not to mention participation and obedience to external laws". 9 In this position, control is not a direct element of accountability but "is the necessary (if not sufficient) condition for its exercise". ${ }^{10}$ Control then, is not the function of accountability mechanisms. Bowling and Foster contend that accountability: “. . involves a duty to account for actions taken, to explain them, and for the police to be cooperative with an external, independent authority and ultimately with the wider community". ${ }^{11}$

This emphasis on community cooperation moves towards a situation where the views of bodies external to the police have a role in the decisions taken by the force. There is still no suggestion as to what should happen where there is general dissatisfaction for the explanation provided, making this definition incomplete. Bayley has defined an accountable police force as: ". . . one whose actions, severally and collectively, are

3 See, generally, J Chan, "Changing police culture" (1996) 36(1) British Journal of Criminology 109; J Fleming and $G$ Lafferty, "New management techniques and restructuring for accountability in Australian police organisations" (2000) 23(2) PIJPSM 154; D Currie, W DeKeseredy and B MacClean, "Reconstituting social order and social control: police accountability in Canada" (1990) 2(9) Critical Criminology 29; Lustgarten, The Governance of the Police (n. 1 above); E McLaughlin, "The democratic deficit: European Union and the accountability of the British police" (1992) 32(4) British Journal of Criminology 473; D H Bayley, Patterns of Policing (New Brunswick: Rutgers UP, 1990); L Johnston, "Controlling the police" (1987) 3(1) Policing 48; Jefferson and Grimshaw, Controlling the Constable (n. 1 above).

4 G Ellison and J Smith "Bad apples or rotten barrel? Policing in Northern Ireland" in O Marenin (ed.), Policing Change, Changing Police: International perspectives (New York: Garland Publishing Inc, 1996); A Mulcahy, Policing Northern Ireland: Conflict, Legitimacy and Reform (Culompton: Willan, 2006); C Shearing, "Reinventing policing: police as governance" in O Marenin (ed.), Policing Change, Changing Police: International perspectives (New York: Garland Publishing Inc, 1996).

5 J Connolly, "Policing Ireland: past, present and future" in P O'Mahony (ed.), Criminal Justice in Ireland (Dublin: Institute of Public Administration, 2002); D Walsh, "The proposed Garda Síochána Ombudsman Commission: a critique” (2004) 14(1) ICLJ 2; B Vaughan, "A new system of police accountability” (2005) 15(3) ICLJ 18; V Conway, "An Garda Síochána Act 2005: breaking down the thick blue wall?” (2005) 23 ILT 297; B Vaughan and S Kilcommins, "The Europeanization of human rights: an obstacle to authoritarian policing in ireland?” (2007) 4 EJC 437.

6 For a discussion of the drivers of police reform see P Stenning and C Shearing "Reforming police: opportunities, drivers and challenges" (2005) 38(2) Australian and New Zealand Journal of Criminology 167.

7 Chan, "Changing police culture" (n. 3 above).

8 Marshall, "Police accountability revisited (n. 1 above); Brogden et al., Introducing Police Work (n. 1 above); Jefferson and Grimshaw, Controlling the Constable (n. 1 above); Reiner, The Politics of the Police (n. 1 above); B Bowling and J Foster, "Policing and the police" in M Maguire, R Morgan and R Reiner (eds), The Oxford Handbook of Criminology (Oxford: OUP, 2007).

9 Day and Klein (n. 1 above), p. 109

10 Ibid., p. 114.

11 Bowling and Foster, "Policing the police" (n. 8 above), p. 1015. 
congruent with the values of the community in which it works and responsive to the discrepancies when they are pointed out". ${ }^{12}$

This definition seems to overcome this problem to an extent, although it only tells what an accountable force should look like, and not how it is to be achieved.

On the other hand Lustgarten, in his seminal work, The Governance of Police, ${ }^{13}$ linked accountability directly with control. For him, it centres on how political institutions manage to govern the police and so accountability (or control) is achieved through the tripartite system, in the work of the police authorities and the Home Secretary with the Chief Constable. ${ }^{14}$ Many respected commentators agreed. Reiner and Spencer argued that controlling police actions was "the fundamental problem". ${ }^{15}$ Even the title of Jefferson and Grimshaw's book, Controlling the Constable, ${ }^{16}$ indicates the centrality of control. They believe "accountability concerns the institutional arrangements designed to ensure the obligations of the police are upheld". ${ }^{17}$ Explanations for behaviour have a limited function in this model, as resort to them means that attempts to control the police have failed.

This bifurcation was identified by Marshall, who demarcated two competing forms of accountability - the "subordinate and obedient" model and the "explanatory and cooperative" model. ${ }^{18}$ He saw subordinate and obedient accountability as a "mode in which the supervisor's responsibility is typically accompanied by administrative control and the ability to direct and veto". ${ }^{19}$ Explanatory and co-operative accountability was a new mode he recommended, which "rests not on an ability to issue orders but on the capacity to require information, answers and reasons that can then be analysed and debated in Parliament and in the press". ${ }^{20}$ As to whether one should be preferred, there are problems with each. ${ }^{21}$ In terms of explanatory accountability, it can be questioned how asking the police to tell stories about their use of powers is going to achieve accountability. And critics of the control mode argue that it will be ineffective because of cultural resistance and the gap between policy and practice. Chan ${ }^{22}$ contends that they need not be viewed quite so exclusively and that they arguably have the same ultimate goal in mind: the legitimating of powers conferred on the police. Indeed, it is submitted, that for a system of accountability to be effective then it should aim to govern the police and secure explanations. At the very least, prior to engaging in a process of reform, a state should consider what accountability should achieve within the particular context. Without a clear vision as to their purpose, reforms cannot make a police force accountable for the powers which it uses, both at an individual and an institutional level. It would be like building a house without foundations - you might erect a structure, but it won't stay that way for very long.

Northern Ireland is one jurisdiction which did take such a considered approach in the reform of police accountability. The Report of the Independent Police Commission in Northern

12 D H Bayley, "Accountability and control of the police: lessons from Britain" in T Bennett (ed.), The Future of Policing: Papers presented to 15th Cropwood Round Table Conference (Cambridge: Institute of Criminology, 1983), p. 36.

13 Lustgarten, The Governance of the Police (n. 1 above).

14 Ibid., p. 113.

15 Reiner and Spencer, Accountable Policing (n. 2 above), p. 170.

16 Jefferson and Grimshaw, Controling the Constable (n. 1 above).

17 Ibid., p. 10.

18 Marshall, "Police accountability revisited" (n. 1 above), p. 61.

19 Ibid.

20 Ibid., p. 62.

21 See Lustgarten, The Governance of the Police (n. 1 above) and Brogden et al., Introducing Police Work (n. 1 above).

22 Chan, "Changing police culture" (n. 3 above). 
Ireland $^{23}$ led to, among other things, a fundamental overhaul of policing and police accountability in that jurisdiction, one of the most contested issues of the Peace Process. The change in police title from Royal Ulster Constabulary to Police Service of Northern Ireland, the establishment of the Office of the Police Ombudsman for Northern Ireland, the Policing Board, and the District Policing Partnership Boards were heralded by the proposing committee as "A New Beginning" for policing in Northern Ireland. ${ }^{24}$ These changes have been seen by numerous commentators as an example of best practice, a blueprint for future changes in other countries. ${ }^{25}$ Ellison describes it as "a useful template for the establishment of democratic policing internationally". ${ }^{26}$ However, police reform should be jurisdictionally specific to accord with the variations and cultural differences which shape policing. It would be wrong to suggest that these mechanisms can be simply transposed into another context, without consideration of the social, cultural, political and financial factors which undeniably influence how the police utilise their powers, and how the public respond to the police. This is not to say however, that the Patten Report is not of relevance to other jurisdictions and this paper will suggest how it could be interpreted. By firstly examining the report, and the theoretical research which led to the specific reforms mentioned above, it will be argued that what Patten does provide is a conceptual background to the specific recommendations which can serve as a framework for reform in other jurisdictions. The paper will then consider what happens when a jurisdiction fails to engage with the general framework of accountability when undergoing reform, by analysing the recent experiences of the Republic of Ireland. There, the merits of policy transfer were acknowledged, and the recommendations of the Patten Report were argued by many to be the best way forward, but they advocated the specific bodies which had been suggested for Northern Ireland. It will be contended that had Ireland proceeded using the theoretical basis of the Patten Commission, rather than just adopting the structures, then it could have implemented a more holistic accountability system. As it is, Ireland never questioned what police accountability should mean for An Garda Síochána, the national police force. Instead, police accountability reform in Ireland has been piecemeal and kneejerk with the result that systemic problems have not been addressed, and the potential for further abuses has not been negated.

\section{The Patten Commission: a framework for accountability}

The Royal Ulster Constabulary was the police force of Northern Ireland from 1922 to 2001.27 During the Northern Irish Conflict, the legitimacy of the RUC was particularly contested. ${ }^{28}$ Its largely Protestant membership and association with the state made it unacceptable to many members of the Nationalist community. Throughout the Conflict the RUC was highly involved in violent exchanges, with many allegations of abuse of power, force and collusion being made. ${ }^{29}$ One of the primary focuses of the Peace Process in the 1990s was to enhance the legitimacy of policing in Northern Ireland. The Patten Commission was established under the terms of the Belfast Agreement to bring policing in

23 C Patten, Report of the Independent Police Commission in Northern Ireland (London: HMSO, 1999).

24 C Shearing, "A new beginning for policing" (2000) 27(3) Journal of Law and Society 386.

25 G Ellison, "Police reform, political transition, and conflict resolution in Northern Ireland" (2007) 10 Police Quarterly 243.

26 Ibid., p. 244.

27 G Ellison and J Smyth, The Crowned Harp (London: Pluto Press, 2000)

28 J Smyth, "Symbolic power and police legitimacy: the Royal Ulster Constabulary" (2002) 38 Crime, Law and Social Change 295; Mulcahy, Policing Northern Ireland (n. 4 above).

29 A Mulcahy, "Policing history: the official discourse and organisational memory of the Royal Ulster Constabulary" (2000) 40 British Journal of Criminology p 68. 
line with the stated commitment to use "peaceful and democratic means to resolve differences". ${ }^{30}$ Beginning work in June 1998, the Patten Commission reviewed international policing literature and debates, received 2500 written submissions, petitions signed by thousands of individuals, and held meetings at which over 10,000 people attended. ${ }^{31}$ The report made over 175 recommendations over nineteen identified thematic areas of policing - including governance, mandate, accountability, training, human rights, cultural symbolism, and recruitment - many of which have now been implemented. ${ }^{32}$

In relation to its work on accountability, the reflective approach which the Patten Commission took - combining literature review, community consultation and visits to police services internationally - enabled it to take an open-minded approach, exploring best-practice and other innovations, in an effort to explore what should be done to create an accountable police force. Only then did it turn to the problem of how this could be made to fit within Northern Ireland. In addressing the question of what accountability should achieve, the Patten Commission agreed with the work of Marshall and Chan that any police force should be held to account in both the controlling and explanatory senses. ${ }^{33}$ With this as its goal, Patten identified five forms of accountability which together, it was hoped, would incorporate the twin elements and deliver a robust framework of accountability: these were democratic accountability, transparency, legal accountability, financial accountability and internal accountability. Working from this framework, the Patten Commission also asked in relation to any proposed reform the following five questions:

1. Does the proposal promote efficient and effective policing?

2. Will it deliver fair and impartial policing, free from partisan control?

3. Does it provide for accountability, both to the law and to the community?

4. Will it make the police more representative of the society they serve?

5. Does it protect and vindicate the human rights and dignity of all?

The tests for any proposal, while perhaps directed at particular concerns in the jurisdictional context, outline standards which any police force in a democratic state should aim to meet. Taking the five forms of accountability and applying these tests, the Patten Commission developed a new system of accountability for the police of Northern Ireland.

The nature of police powers, which the public cede for the protection of individual rights and the maintenance of order, demands that the public has some democratic means of holding the police to account. This ensures that all policing is by consent, thus enhancing its legitimacy. Democratic accountability performs both controlling and explanatory functions by enabling the public to inform the police as to the type of service it wishes to be delivered and to then hold the police to account for that service. ${ }^{34}$ In the UK, democratic accountability is supposed to be achieved through the Police Authority, under the tripartite structure implemented by the Police Act 1964. This divides governance duties between the

30 "The participants believe it essential that policing structures and arrangements are such that the police service is professional, effective and efficient, fair and impartial, free from partisan political control; accountable, both under the law for its actions and to the community it serves; representative of the society it polices, and operates within a coherent and cooperative criminal justice system, which conforms with human rights norms."; Patten, Report (n. 23 above), p. 26.

31 Ibid.

32 Ellison, "Police reform" (n. 25 above).

33 Patten, Report (n. 23 above), p. 22.

34 Ibid.; I Loader, "Democracy, justice and the limits of policing: rethinking police accountability" (1994) 3 Social and Legal Studies 521. 
Chief Constable, the Policing Authority and the Home Secretary, though the roles of each are vague and uncertain, leaving the reality of police governance particularly unclear. ${ }^{35}$

The Patten Commission, in its review of the pre-existing position in Northern Ireland, determined that the Police Authority meant "the public have not been able to hold the police accountable through their democratically elected representatives". 36 They took issue with the process of appointment to the authority, but, more than anything, the involvement of British politicians ensured that the public did not, through its representatives, make the RUC subordinate in the sense that Marshall would have advocated. Instead, the Patten Commission recommended the establishment of a Policing Board, ${ }^{37}$ comprised of nineteen members; ten coming directly from the elected assembly, and the other nine independent members stemming from a variety of backgrounds and expertise. The term "operational independence" which had prevented control from being exercised was replaced with the term "operational responsibility", which they felt more closely reflected the requirements of an accountable police service. To this end the Policing Board was given the power to demand explanations for operational decisions from the chief constable. Additionally, the Patten Commission recommended a further democratic body, in the form of District Policing Partnership Boards, which through decentralisation would encourage engagement and discussion between policing districts and their immediate communities.

Transparency is achieved primarily through the public dissemination of information on policing, in a proactive, rather than a reactive manner. Dissemination will, for most police forces, require a fundamental change of culture. The natural inclination is for police forces to be "defensive, reactive and cautious" in providing information but, for real transparency, police must adopt a culture of openness: "People need to know and understand what their police are doing and why ... Secretive policing arrangements run counter not only to the principles of a democratic society but also to the achievement of fully effective policing." 38

In the Northern Irish context, it was envisaged by the Patten Commission that both the Policing Board and the District Policing Partnership Boards would meet in public once a month. But more than this, the concept should be infused into policing that unless it is in the public interest not to disclose something then all information about policing should be available to the public. As the Patten Commission described, "transparency is not a discrete issue but part and parcel of a more accountable, more community-based and more rightsbased approach to policing". 39

35 Marshall, "Police accountability revisited" (n. 1 above); Lustgarten, The Governance of the Police (n. 1 above); R Reiner "Policing a postmodern society" (1992) 55(6) MLR 761; Reiner and Spencer, Accountable Policing (n. 2 above); T Jones, T Newburn and D J Smith, Democracy and Policing (London: Policy Studies Institute, 1994); D Dixon, "Legal regulation and policing practice" (1992) 1 Social and Legal Studies 515; S Walker, The New World of Police Accountability (Thousand Oaks: Sage, 2005) I Loader "Plural policing and democratic governance" (2000) 9(3) Social and Legal Studies 323; M Kempa, "Tracing the diffusion of policing governance models from the British Isles and back again: some directions for democratic reform in troubled times" (2007) 8(2) Police Practice and Research 107.

36 Patten, Report (n. 23 above), para. 5.5.

37 Note that throughout, Patten refers to policing rather than the police, preferring a more inclusive and realistic approach to these issues in Northern Ireland. The responsibilities of such a board would be to set objectives and priorities for policing, adopt a policing strategy reflecting those objectives and priorities, adopt an annual policing plan, and negotiate the budget with government. It would monitor police spending and performance against the annual plan and the long-term strategy. It should assess public satisfaction and complaints as well as having responsibility for senior appointments.

38 Patten, Report (n. 23 above), para. 5.14.

39 Ibid., para. 6.38. 
The legal aspect is often seen as the most obvious face of police accountability, and police forces have often argued that they should be accountable to the law and the law alone, ${ }^{40}$ as it is from the law that they receive their powers. Current thinking, as embodied by the work of the Patten Commission, sees this as just one aspect of a broader, holistic framework of accountability. ${ }^{41}$ It is most obviously achieved through complaints systems, although civil and criminal actions against officers also have a role. Complaints systems are charged with a difficult task; not only are they expected to secure police accountability, but they are also very definitely linked to public confidence in the police. The Patten Commission called for the full implementation of the Hayes Report, which had advocated the establishment of a Police Ombudsman's Office to take over the handling of complaints from the public. This Office came into being in 2000 and, unlike many other such models, it is entirely independent and, most importantly, it investigates all complaints against the police itself and can initiate investigations of its own accord. The office has also worked hard to promote its work and publicise its findings and research would indicate that it is perceived to be legitimate in the eyes of the public. ${ }^{42}$

Also included in legal accountability could be civil and criminal actions against a police force which equally seek to hold police officers accountable to the law. Indeed, the complaints mechanism, if independently operated, can often be a means of a case being sent to the Director of Public Prosecutions. ${ }^{43}$ While Patten was adamant that where criminal activity had occurred it should be criminally investigated, the Patten Commission did not feel that civil actions should be a feature of an effective system of accountability. If both control and explanation are being achieved through state mechanisms then there should be limited recourse to civil actions.

Policing is an expensive business and the public is entitled to question how its money, generated through taxes, is being spent. This was an area which the Patten Commission felt required general enhancement with more developed systems of audit and planning. This is also an area which could be considered a controlling form of accountability. Financial accountability has become a predominant feature in discussions of policing in the UK, since the "managerial turn" in British politics. 44

Finally, the Patten Commission felt that the work done internally is "critically important" and many instances of police misconduct and public disquiet could be avoided if internal accountability was strengthened. While internal systems inherently concern disciplinary procedures, they do also involve management. Clarity as to the role of each individual within the system is vital as well as an appraisal system, ensuring appropriate understanding of and training for the role. The Patten Commission even recommended that such a system should form part of the promotion and selection process. Related to this issue is the need for greater flexibility in the dismissal processes within police forces. The Patten Commission pointed to the difficulties faced by forces in the UK in dealing with "ineffective or incompetent" officers in the past and supported moves which sought to ease this process.

This framework, combining five different forms of accountability, is thorough and well rounded. It provides for both the controlling of police activity - through developed internal mechanisms, financial constraints, and the knowledge that actions will be public and

40 As per Lord Denning in R v Blackburn [1968] 2 QB 118 and R Mark, Policing a Perplexed Society (London: Allen \& Unwin, 1977).

41 Vaughan, "A new system" (n. 5 above).

42 M Seneviratne "Policing the police in the United Kingdom" (2004) 14(4) Policing and Society 329.

43 G Smith, "Police complaints and criminal prosecutions" (2001) 64(3) MLR 372.

44 McLaughlin, "The democratic deficit" (n. 3 above); Loader, "Democracy, justice and the limits of policing" (n. 34 above); Smith, "Police complaints" (n. 43 above). 
scrutinised - and the provision of explanations for policing decisions - through continuous interaction and answerability to politicians and the public, independent bodies that will investigate complaints, and an overarching framework of transparency. A variety of innovative mechanisms have been put in place to achieve these goals, which all contribute to this framework.

\section{Importing Patten: the Irish debate}

The Republic of Ireland is policed by one, national police force, An Garda Síochána. ${ }^{45}$ Until 1986, police accountability in Ireland was secured either through the internal handling of complaints, or through the questioning of the Minister for Justice in Parliament. ${ }^{46}$ A number of scandals in the early 1980s, legislation which enhanced the powers of the police, as well as developments in the UK, prompted reform and the Garda Síochána Complaints Board was established in $1986,{ }^{47}$ though the will for reform was weak. In the context of the Northern Irish Conflict, which was resulting in the deaths of members of An Garda Síochána for the first time in thirty years, ${ }^{48}$ little impetus existed for critical evaluation of policing or rigorous accountability. This is reflected in the role of the new mechanism which handled citizen complaints about individual officers and nothing more. While the board which reviewed cases comprised members external to the police force, all investigations were conducted by police officers, and the system was significantly under-resourced. ${ }^{49}$ Opposition to the Bill did not focus on its shortcomings. Rather it was argued that:

Many Gardaí feel genuinely hurt that they, and their profession, should be held in such low esteem by the Government that they can no longer be trusted, can no longer be accorded the same rights and respect as all other public servants not to mention the criminals. At a time when Gardaí are under siege from all sides the least they could have hoped for was that their own Minister for Justice would not add to the cacophony of abuse, but would instead do something to boost flagging morale . . . how more accountable are they going to have to become before the Government is satisfied? 50

In practice, however, the Complaints Board was neither independent nor effective and, while numerous commentators continually called for reform, the public continually reported particularly high levels of confidence in the force throughout the life of the Complaints Board, ${ }^{51}$ giving politicians little reason to legislate otherwise. In 2002, however, a Tribunal of Inquiry was established to investigate serious allegations of corruption and

45 Meaning "Guardians of the Peace".

46 D Walsh, The Irish Police (Dublin: Round Hall/Sweet \& Maxwell, 1998).

47 Vaughan and Kilcommins, "The Europeanization of human rights" (n. 5 above).

48 In the fifteen years preceding this legislation, ten members of An Garda Síochána had been killed by members of paramilitary organisations, a sizeable number in a country which had not seen an officer killed for twentyeight years before that.

49 On one occasion, the board was forced to suspend operations due to under-resourcing; The Irish Times, 16 December 1989.

50 Frank Prendergast, Dáil Debates, 20 March 1986, vol. 364, col. 2493.

51 Garda Public Attitude Surveys have placed public confidence in the national police at between 79-87\% over the last six years: P Kennedy and C Browne, Garda Public Attitudes Survey (Templemore: GRU, 2007); P Kennedy and C Brown, Garda Public Attitudes Survey (Templemore: GRU, 2006); Garda Research Unit, Garda Public Attitudes Survey (Templemore: GRU, 2005); K Sarma and K O’Dwyer, Garda Public Attitudes Survey (Templemore: GRU, 2004); K Sarma, Garda Public Attitudes Survey (Templemore: GRU, 2003); Garda Research Unit, Garda Public Attitudes Survey (Templemore: GRU, 2002). 
misconduct. The Morris Tribunal ${ }^{52}$ in its damning reports has substantiated claims of widespread corruption in one policing district, which included officers planting "finds" of IRA bombs in order to gain promotion, the framing of two innocent men for murder, unlawful arrest, abuse of detainees and a pervading unwillingness to account for actions taken. These findings, together with continual calls from a number of bodies for reform ${ }^{53}$ and the influence of the changes which had taken place throughout the UK in the preceding years, led to the passing of the Garda Síochána Act 2005, which instituted fundamental reforms in how accountability was to be achieved in Ireland. Further, the declining impact of the Northern Irish Conflict, through the successes of the Peace Process, negated to an extent the protection afforded to An Garda Síochána by the Government from external audit and control. Indeed, under the terms of the Good Friday Agreement, the Irish Government had made a commitment to enhance the protection of human rights in the country. ${ }^{54}$ This had lead to the establishment of the Human Rights Commission and to the incorporation of the European Convention on Human Rights into domestic legislation. In this way, Vaughan and Kilcommins argue that "Human rights development acted like a magnet, pulling the institutions of the Republic along to the level reached in Northern Ireland" 55 and so developments in the North were inherently influential in the legislative debates in the South.

The Irish Government had expressed its intention to reform the accountability of An Garda Síochána in 2002. The Heads of the Bill were published in 2003 and the Act was passed in 2005. The Act represented the most substantial reform of the police force since its establishment in 1922, and the debate over this three-year period reflected this significance. The recommendations of the Patten Report featured prominently in that debate, particularly given the proximity in geography and time and the Government's

52 Morris Tribunal, Reports of the Tribunal of Inquiry set up Pursuant to the Tribunal of Inquiry (Evidence) Acts 1921-2003 into Certain Gardai in the Donegal Division: Term of Reference (e): 'Report on explosives 'finds' in Donegal" (2004); Terms of Reference (a) and (b): "Report of the investigation into the death of Richard Barron and extortion calls to Michael and Charlotte Peoples" (2005); Term of Reference (d): "Report on the circumstances surrounding the arrest and detention of Mark McConnell on 1 October 1998 and Michael Peoples on 6 May 1999" (2006); Term of Reference (g): "Report on the Garda investigation of an arson attack on property situated on the site of the telecommunications mast at Ardara, Co. Donegal in October and November of 1996" (2006); Term of Reference (i): "Report on the arrest and detention of seven persons at Burnfoot, Co. Donegal on 23 May 1998 and the investigation relating to same" (2006); Terms of Reference (b), (d), and (f): "Report on the detention of 'suspects' following the death of the late Richard Barron on 14 October 1996 and related detentions and issues" (2008); Term of Reference (h): "Report into allegations contained in documents received by Deputy Brendan Howlin on 25 June 2000 that two senior members of An Garda Síochána may have acted with impropriety" (2008); Term of Reference (c): "Report into allegations of harassment of the McBrearty family of Raphoe, Co. Donegal, and of relatives, associates and agents of that family by members of the Garda Síochána and subsequent to the death of $\mathrm{Mr}$ Barron including the issue and prosecution of summonses relating to offences alleged to have occurred between 28 October 1996 and 28 September 1998” (2008); and Term of Reference (j): "Report into the effectiveness of the Garda Síochána complaints inquiry process vis-à-vis the complaints made by Frank McBrearty Snr and his family between 1997 and 2001" (2008).

53 Walsh, "The proposed Garda Síochána Ombudsman Commission" (n. 5 above); Irish Human Rights Commission, Proposal for a New Garda Complaints System (Dublin: IHRC, 2002); European Committee for the Prevention of Torture, Report to the Government of Ireland on the Visit to Ireland Carried out by the European Committee for the Prevention of Torture and Inbumane or Degrading Treatment or Punishment (Strasbourg: CPT, 1998); European Committee for the Prevention of Torture, Report to the Government of Ireland on the Visit to Ireland Carried out by the European Committee for the Prevention of Torture and Inhumane or Degrading Treatment or Punishment (Strasbourgh: CPT, 2002); European Committee for the Prevention of Torture, Report to the Government of Ireland on the Visit to Ireland 2-13 October 2006 Carried out by the European Committee for the Prevention of Torture and Inhumane or Degrading Treatment or Punishment (Strsabourg: CPT, 2007).

54 Vaughan and Kilcommins, "The Europeanization of human rights" (n. 5 above).

55 Ibid., p. 451. 
involvement in the Peace Process. That it was a factor in the debate is unsurprising. What is important to analyse, however, is the way in which the report and its recommendations were presented in that debate, and how this influenced the reforms introduced.

Two opposition parties, Fine Gael and Labour, had actively called since 2000 for the establishment of a Garda Authority, county liaison committees and a Garda Ombudsman, concepts which were "unapologetically derived from much of the work of the Patten Commission". ${ }^{56}$ In 2001, the Labour Party proposed a motion to Parliament for these reforms and in the debate clearly expressed its dedication to the principles of Patten: "Much of the Patten report recommendations set out best practices for policing that would be applicable in any modern society ... We should not be afraid to borrow from the Patten report." 57

This borrowing, however, was piecemeal in nature with no explanation as to why some of the 175 recommendations were deemed relevant to Ireland and some were not. Certainly, the measures they call for would incorporate both explanatory and controlling elements of accountability but, for instance, the core recommendations of Patten in relation to internal accountability are ignored. It is instead recommended that the disciplining of senior officers be assigned to the new Garda Authority, a suggestion which had no basis in the Patten Report. A year later, the Irish Human Rights Commission published A Proposal for a New Garda Complaints System which, in making specific reference to the Patten Report, called for the establishment of an ombudsman and explored the possibility of a policing board. But the premise of the document was to reform the complaints system and not to evaluate police accountability as a whole. No mention is to be found of democratic or internal accountability. Transparency is mentioned but as a principle which should underpin the new complaints system. It seems incongruous that a group aiming to promote human rights in Ireland would focus on the explanatory mode of accountability rather than on controlling police behaviour (and the police's capacity to breach human rights) in the first place.

The Irish Council for Civil Liberties (ICCL) took the connection to Northern Ireland further in its policy paper, Why Patten Should Apply Here and How this can be Achieved, in which it called for a commitment to human rights, a more representative force, and the establishment of an Ombudsman Commission and a Policing Board. The ICCL stated that, in relation to citizen complaints, "there is no need for the Irish Government to 're-invent the wheel' on this issue", 58 yet in the same document the ICCL seeks reform in the areas of whistleblowers, police powers, interrogation of suspects, recording of interviews and access to lawyers while in custody, without mentioning the Patten Report. The implication is that the mechanisms required to make An Garda Síochána an accountable police force are different to what was required in Northern Ireland. This inherent contradiction continued to be apparent in the ICCL's submission on the government proposals for reform later that year in which the it contended that:

The work carried out by the Patten Commission is the most comprehensive study of police structures ever undertaken in a common law legal system, and we believe that the recommendations contained in its report represent best international practice in policing. 59

56 Labour Party, Proposals for Legislation for a Garda Authority and Garda Ombudsman (Dublin: Labour Party, 2000), p. 2.

57 Brendan Howlin, Dáil Debates, 10 April 2001, vol. 534, col. 606.

58 Irish Council for Civil Liberties, Why Patten Should Apply Here and How This Can Be Acbieved (Dublin: ICCL, 2003), para. 3.12.

59 Irish Council for Civil Liberties, Submission on Scheme of Garda Siochána Bill (Dublin: ICCL, 2003), p. 4. 
Connolly ${ }^{60}$ reviewed the state of accountability within An Garda Síochána, looking at complaints, accountability to the courts and to politicians. In finding each lacking, he referred to the Patten Report and the "various mechanisms in that report which I think would be of great benefit in this jurisdiction". ${ }^{61} \mathrm{He}$ then discussed the impact of the Policing Board, the District Policing Partnership Boards and the Police Ombudsman, indicating that such mechanisms could enhance democratic accountability in Ireland. Again however, the emphasis is on the specific institutions and bodies recommended by the Patten Report rather than a dedication to the overarching principles enshrined in that document.

On the publication of the heads of the Garda Síochána Act, one newspaper was scathing in its criticism of the legislation for its failure to incorporate the Patten recommendations to a greater extent:

The Taoiseach and his colleagues have been vocal and resolute supporters of the Patten reforms, designed to transform policing in the North. The work of the Patten Commission is a ready-made blueprint for a new era of policing here ... Why does McDowell [the Minister for Justice responsible for the legislation] consider it to be right for the people of the North, but inappropriate for those on this part of the island? ${ }^{62}$

The answers given to this question were various; they are two different jurisdictions, policing in the North is far more contentious, the Gardaí have always maintained high levels of public support, Ireland is a bigger jurisdiction, and so on. ${ }^{63}$ These are certainly all true and are perhaps valid reasons for arguing that Ireland should not implement the same mechanisms as were implemented in the North. The problem with this debate is that at no point was the suggestion made that Ireland should adopt from Patten the strong theoretical framework, as amended for practical implementation in Ireland. Each of these critics focused on the possibility of reproducing the specific institutions recommended by Patten for Northern Ireland, rather than adopting the theoretical approach which would involve determining what police accountability should achieve and what areas need to be reformed in order to do that. Each of the individuals and bodies mentioned above argued for the implementation of the Patten Report, but then proceeded to cherry-pick certain recommendations as suitable for Ireland. None of these engage with the question of what accountability should achieve. None mentioned internal or financial accountability and only Connolly discusses democratic accountability. There was no framework or overarching scheme to any of these analyses. At the very least, the five tests which Patten had adopted as its benchmark could have been utilised by the opposition and interested parties to critique government proposals.

In presenting this Bill to the Houses of Parliament, the Minister for Justice outlined the Government's position in respect of it. He stated that it "contains the most comprehensive and, I believe, the most important, legislative proposals on policing ever to come before the House". ${ }^{64}$ He expressed a need to learn from developments in Northern Ireland and, indeed, used much of the language from the Patten Report: "operational responsibility", "financial responsibility", "democratic accountability", "open and transparent". The influence of Patten was apparent but the Minister for Justice's statement that the twin objectives of the Bill were to reform management structures and to implement a new

60 Johnny Connolly, "Do We Need Patten Type Reforms in the Republic", speech at James Connolly Education Trust, 24 October 2008, http://www.iol.ie/ sob/jcet/2000-10-24-jc.html (accessed 17 November 2008).

61 Ibid., p. 7.

62 The Sunday Business Post, 3 August 2003.

63 Michael McDowell, Seanád Debates, 2 March 2004, vol. 175, col. 1310.

64 Ibid. 
complaints mechanism make it clear that the theoretical framework of Patten became lost in translation. The debate on police reform in Ireland never engaged with such concepts. The Act of 2005 implemented a great number of reforms and new institutions including an Ombudsman Commission, Joint Policing Committees, a Garda Inspectorate, a duty to account, new financial responsibility arrangements, a new Promotions Board and a Whistleblowers' Charter. So how is accountability achieved now?

Prior to the 2005 Act, democratic accountability in Ireland was achieved solely through the Minister for Justice who answered questions on policing in the state to both the Dáil and the Senate. ${ }^{65}$ The Minister for Justice was only in control of finance and internal regulations, and not responsible for of the direction and control of the force which rested with the Garda Commissioner, with the result that the Minister for Justice could only serve as a conduit for information provided by the Garda Commissioner. ${ }^{66}$ Further, Walsh's shows that, despite the Houses of Parliament being the sole arena of democratic accountability, there was limited criticism of An Garda Síochána expressed there. ${ }^{67}$ The opposition feared political backlash given the popularity of An Garda Síochána and the Government was slow to criticise the Garda Commissioner whom it appoints and works closely with. As one minister stated:

While people in this House and people in the media may have freedom to criticise, the Government of the day should not criticise the Garda Síochána . . . it is obscene that the Government and the Minister responsible should be the first to lead the charge in the criticism of the Garda Síochána. ${ }^{68}$

Comments like this led Walsh to conclude the role of the Minister of Justice "could be interpreted as being designed to protect the Garda against the full rigours of democratic accountability". ${ }^{69}$ Democratic accountability was not providing a mechanism whereby the public could "be able to satisfy itself that it is getting value for money from the police force and that the substantial legal and moral authority entrusted to the force is not being abused". 70

In spite of this it did not feature in the reform debates, beyond addressing specific issues raised by the Morris Tribunal, though the 2005 Act did introduce a number of measures of relevance. The relationship between the Minister for Justice and the Garda Commissioner is clarified somewhat with the former now approving the annual policing plan, and threeyear policing strategy. The Garda Commissioner is also now under a duty to account to the Minister for Justice and to provide any information requested by that minister. ${ }^{71}$ The Minister for Justice can also order the establishment of an inquiry to investigate any matter of administration, practice or procedure of the force as he or she sees fit. Government, thereby, has a much stronger role in policing policy and accountability. Nonetheless, this reformulation continues the arrangement of democratic accountability being located within this one relationship. The problem lies in the driving force behind this reform. It was not an effort to create the most robust structures but a reaction to one incident in the run-up to the establishment of the Morris Tribunal in which the Garda Commissioner failed to

65 Connolly, "Do We Need Patten Type Reforms" (n. 60 above).

66 Walsh, "The proposed Garda Síochána Ombudsman Commission” (n. 5 above), pp. 376-97.

67 D Walsh, The Irish Police (Dublin: Round Hall/Sweet \& Maxwell, 1998).

68 Michael Noonan, Dáil Debates, 10 November 1987, vol. 375, col. 227.

69 Walsh, "The proposed Garda Síochána Ombudsman Commission” (n. 5 above), p. 402.

70 Ibid., p. 367.

71 Garda Síochána Act 2005, ss 20-5. 
provide the Minister for Justice with the findings of an internal inquiry. ${ }^{72}$ This is perhaps a prime example of an exposed defect which was responded to in an enthusiastic manner, but without stepping back to assess the overall nature of the problem revealed. Had this been done, it might have been seen that the reliance on this relationship to deliver democratic accountability is inherently weak, and rather than reforming it, a different model of democratic accountability should be preferred. The problem lies with the questioning of the Minister for Justice through the parliamentary process and, in fact, it could be argued that, having approved policing plans, the Minister for Justice will now have a greater political interest in the position of An Garda Síochána. Questions from the opposition on garda operations may now become encased in party politics, further diminishing their capacity for achieving accountability.

The opposition calls for a Garda Authority may appear as a solution to this dilemma, although Kempa has urged caution in this regard, indicating that "it is a universally held view in academia that Police Authorities have never lived up to their promise as agencies that would achieve the 'democratization' of policing". ${ }^{73}$ That said, Kempa proceeds to argue that developments in Northern Ireland, with the replacement of the Police Authority with a Policing Board, are "radically" transferring power from government to the community. What is certain in the Irish context is that Joint Policing Committees (JPCs), ${ }^{74}$ forums for consultation, discussion and recommendations on policing matters affecting the local authority's administrative area, cannot perform that function. The explanatory memorandum to the Bill clearly stated that JPCs could make recommendations to the Gardaí but in no way was the force formally accountable to them. Each must hold at least one public meeting a year, but it is difficult to imagine that one meeting a year can lead to real and effective consultation between the community and the police. The Northern Irish counterparts, the District Policing Partnership Boards, meet six times a year, which seems a viable way of forming solid communication and relationships between those involved. The issues which the public have in relation to the policing of their communities are likely to change with relative frequency and if the JPC is not meeting regularly, and not addressing each of these issues, then it will be ineffective and become the "lame-duck" in the eyes of the public which Kempa described.

The JPCs are supposed to achieve greater transparency, but just one annual meeting is hardly sufficient to achieve this aim. Even now, it is difficult to find information about the existing JPCs under the pilot scheme. Some of the JPCs, most particularly those in Dublin, have published detailed information on their council websites. Dublin City Council, for instance, has available on its website the guidelines, committee membership details, the minutes of meetings held, an annual report, and a workshop report. ${ }^{75}$ This is most certainly the exception, unfortunately, and for cities such as Limerick, Cork and Galway there is no information to be found online. If interested citizens cannot find out how to participate, what hope have these committees of creating real dialogue and engagement? It may well be

72 In 2005, the Minister for Justice, who had been Attorney General at the time of the Carty Inquiry, explained: "Unfortunately, it was the case at the time, doubtless in good faith, that there was a doctrine that the Garda Síochána was in privity with the Director of Public Prosecutions and that it was open to senior Gardaí in consultation with the Office of the Director of Public Prosecutions to decide what the then Minister, Deputy O'Donoghue and myself could see in respect of the investigations being carried out in Donegal."; Michael McDowell, Dáil Eireann, 17 June 2005, vol. 604, col. 519.

73 Kempa, "Tracing the diffusion" (n. 35 above), p. 114.

74 Still in the pilot phase, JPCs have been established in 29 of the 114 local authority areas. A review is currently being held and the guidelines indicate that JPCs will be rolled out in every local authority area subsequently.

75 For details of this JPC, plus those reports visit: http://www.dublincity.ie/yourcouncil/localareaservices/ centralarea/pages/jointpolicingcommittee.aspx (accessed 24 November 2008). 
the case that transparency increases through the information published by the Ombudsman Commission and the Garda Inspectorate, but then this is not derived from the police force itself. Even if the Minister for Justice has greater access to operational decisions, it does not follow that this information will enter the public domain. Little emphasis has been placed on making An Garda Síochána transparent in the proactive way which Patten had envisaged.

The Garda Síochána Ombudsman Commission was established by the Garda Síochána Act 2005 and began its work in May 2007. As the new mechanism for handling complaints, it replaces the Garda Síochána Complaints Board. It is a three-person commission, in spite of arguments favouring the single-person structure in Northern Ireland. Appointments are made by the President, on the nomination of the Government: a missed opportunity to establish an independent appointments panel which would give the Ombudsman Commission complete independence from political interference. ${ }^{76}$ The Ombudsman Commission has already proven itself willing to accept complaints beyond the legally specified time limits, ${ }^{77}$ but it remains the case that, if the subject of the complaint is no longer a member or retires or resigns after the complaint is made, then it is inadmissible

Under the legislation, complaints may be dealt with by way of informal resolution, investigations conducted by Gardaí (supervised or unsupervised) or the Ombudsman Commission will conduct its own investigation. Investigating officers have all the powers, immunities, privileges, and duties of a member of An Garda Síochána and may conduct a search of a station where the Ombudsman Commission permits it. The commission may initiate complaints ${ }^{78}$ and the Garda Commissioner must refer any matter involving conduct of a member for investigation if it resulted in death or serious harm. Further the Minister for Justice may direct the Ombudsman Commission to examine the practice, policy and procedure of the Gardaí.

In the first year of operation, the Ombudsman Commission received 2905 complaints and 294 referrals from the Garda Commissioner, ${ }^{79}$ nearly three times the number of complaints received by the Garda Síochána Complaints Board in its final year of operation..$^{80}$ Most likely this rise is due to the publicity surrounding the creation of the new office, perceived to have greater independence, and a greater willingness on the part of the public to make complaints against An Garda Síochána, rather than any dramatic increase in the rates of misconduct. Indeed, an Ipsos-MORI survey found that 84 per cent of people believe that the Ombudsman Commission will have a positive impact on people's willingness to complain. ${ }^{81}$ Of those complaints from the public which result in an investigation, almost half are still being investigated by the Gardaí and only 10 per cent of those are being supervised by the Ombudsman Commission. Effectively, in these instances, they are being investigated as internal, disciplinary matters. What these numbers also show is that the Ombudsman Commission is at this early point focusing its resources on the most serious investigations, evidenced by the fact that 55 per cent of all investigations concern conduct appearing to involve an offence. These are effectively the only investigations being conducted by the Ombudsman Commission. The main reason for this is under-resourcing. The Ombudsman Commission has yet to reach its full complement of staff. At the end of

76 Irish Human Rights Commission, Observations on the Garda Bill (Dublin: IHRC, 2004).

77 Complaints must be made within six months although the Ombudsman Commission may extend the time if it feels it is justified, as it has already proven itself willing to do in relation to the fatal shooting of two armed raiders in Lusk, Co. Dublin (The Irish Times, 2 October 2007).

78 And must do so where it believes the conduct of an officer has resulted in death or serious harm.

79 Garda Síochána Ombudsman Commission, Annual Report (Dublin: GSOC, 2008).

80 Garda Síochána Complaints Board, Annual Report (Dublin: GSCB, 2006).

81 GSOC, Annual Report (n. 79 above). 
2007 the staff levels of the Ombudsman Commissioner were at 75, though there is the potential for $101 .{ }^{82}$ Even with the full complement of staff, the Ombudsman Commission has expressed the belief that most cases will continue to be investigated by the Gardaí. ${ }^{83}$ The Ombudsman Commission has not been adequately funded to perform its function, to the point where in its first two-year report it has requested the power to "leaseback" the investigation of criminal offences to An Garda Síochána under supervision. This is particularly worrying as it would further dilute the independence of the Ombudsman Commission in a climate where 83 per cent of people believe that it is independent. ${ }^{84}$

Criminal actions, another form of legal accountability, have been difficult to secure in relation to members of An Garda Síochána, as both the investigation process and juries tend to be more biased in favour towards members of the force. Indeed, one member of the Ombudsman Commission, Conor Brady, has stated that "the difficulty of getting convictions from a jury is clear . . Juries are very reluctant. You saw it in the May Day protests, people were seen on television doing unspeakable things, and they were acquitted by a jury." 85 The capacity of criminal actions for achieving accountability is thereby severely limited. On the other hand, civil actions have taken on an increased role in the accountability of An Garda Síochána. This is for two core reasons; firstly, the weakness of the Garda Síochána Complaints Board made many look elsewhere for redress; and, secondly, it reflects a growing litigiousness in Irish society more generally. Civil actions can only have a limited role in terms of accountability, however, as the defendant will be the state or the Attorney General acting in his or her capacity of legal representative of the state, neither of whom can have any impact on Garda practice or policy. Information gathered from Dáil Debates reveals that from 1997 to April 2007 over $€ 17 \mathrm{~m}$ has been paid out in claims against the Gardaí. ${ }^{86}$ The payment of damages does not come from the general policing budget, but, instead, from funds over which the Garda Commissioner has no responsibility or accountability so, as a method of enhancing financial accountability, the payments will have little direct negative impact on the Gardaí.

The 2005 Act also includes provisions relating to the financial accountability of An Garda Síochána. The Garda Commissioner, as Accounting Officer, is answerable to the Public Accounts Committee for matters of spending. The Garda Commissioner is also required under the legislation to establish an Audit Committee within the force, to advise and report to the Minster for Justice on financial matters. This committee will be composed of a Deputy Commissioner and at least four other members, with the relevant skills, and who have never been members of An Garda Síochána. The Garda Commissioner is obliged to furnish the Audit Committee with all information relating to the finances of the force. It must meet four times a year and produce a report which is to be included in the Annual Report of the force, presented to Government. It is supposed to ensure effective, efficient and appropriate use of Garda resources though, as an internal body, issues of transparency will undoubtedly arise.

Internal accountability within An Garda Síochána is built around enforcing the Disciplinary Code, which has been amended regularly, most recently in 2007 . Breach of the Regulations can result in sanctions ranging from being docked pay to demotion or even

82 Personal Communication, researcher Garda Síochána Ombudsman Commission, 7 October 2007. More upto-date figures are not available.

83 Garda Síochána Ombudsman Commission, Annual Report (Dublin: GSOC, 2007).

84 GSOC, Annual Report (n. 77 above).

85 The Irish Examiner, 25 August 2006.

86 Michael McDowell, Minister for Justice, Dáil Eireann, 27 November 2002, vol. 558, col. 509; Dáil Eireann, 23 June 2005, vol. 605, col. 172; Dáil Eireann 04 April 2007, vol. 635, col. 752. 
dismissal, as determined through informal resolution for minor breaches or an investigation for more serious matters. If a member resigns before proceedings against him or her are completed, then that member cannot be disciplined and, in practice, proceedings are halted due to retirement: this has been used by some as a method of avoiding disciplinary action. Walsh has argued "for tightening up the Regulations specifically to permit a disciplinary case to proceed against a member irrespective of his premature resignation", 87 but despite this being a serious issue in the wake of the Morris Tribunal, when many of those criticised resigned before proceedings could be initiated, the Government has not taken action, save to enhance the bureaucracy and legalism of existing mechanisms. The composition of the disciplinary board has also been altered to incorporate external membership. The Garda Commissioner is granted the power of summary dismissal in three specified instances, which is quite a departure from the previous arrangement. Further, the disciplinary regulations now include a duty to account, which, it is hoped, will overcome the problem of officers not explaining actions to senior members. Nonetheless, the procedure is becoming increasingly legalistic and unwieldy.

The Patten Commission saw internal accountability as being a much broader issue than disciplinary proceedings. It highlighted the need for dedicated focus on management, the need to ensure clarity as to job specifications, and the need for an appraisal system to identify individual and system problems. This did not form part of the initial legislative response of the Irish Government. Two reports in 2007 have drawn attention towards the need for reform of these areas. ${ }^{88}$ The final report from the Advisory Group on Garda Management and Leadership Development emphasised, in terms of current changes in the force, that: "There should be performance measurement and appraisal at all levels and that proper arrangements are made for training and staff development to prepare them for their new or changed roles". 89

Taking the corporate world as a sound guide for this area, the Advisory Group felt that in order to achieve the objectives outlined a number of things needed to be done as a matter of priority including clarifying the roles and responsibilities of those in the force and instituting performance evaluation measures. ${ }^{90}$ The Hayes Report also recommended increased training and support for those in management roles, as well as acknowledgment of the different management needs where increasing numbers of recruits are entering the system with a primary degree. Much of this was reiterated by the Garda Inspectorate report published just months later which agreed that:

The Garda HR Strategy must identify means to accelerate the advancement of highly talented people through the various ranks. Specific provision should be made to enable these personnel to acquire the experience, training, education and mentoring necessary to equip them to compete for promotion to the most senior posts in the organisation. ${ }^{91}$

The Association for Garda Sergeants and Inspectors has come out strongly against such a scheme, arguing that promotions of this nature are likely to revert the system to the nepotism which they have worked hard to remove. ${ }^{92} \mathrm{~A}$ lack of faith in the promotions

87 Walsh, "The proposed Garda Síochána Ombudsman Commission” (n. 5 above), p. 250.

88 M Hayes, Report of the Garda Siochána Act 2005 Implementation Review Group (Dublin: Department of Justice, Equality and Law Reform, 2007); Garda Síochána Inspectorate, Report on Senior Management Structures in an Garda Siochána (Dublin: GSI, 2006).

89 Hayes, Report (n. 88 above), p. 7.

90 Ibid., p. 8.

91 Garda Síochána Inspectorate, Report (n. 88 above), p. 21.

92 Joe Dirwan, The Irish Times, 2 October 2007. 
system of the Gardaí would be fatal for the achievement of internal accountability. All parties must work together for what is perceived by all to be a legitimate system in order for it to be successful and to prevent the development of widespread misconduct.

\section{The state of accountability in An Garda Síochána post-reform}

In many respects these reforms do cover the five aspects of accountability outlined by Patten and certainly do provide for both explanatory and controlling accountability. This, however, was not by design, as there was no coherent approach to reform. In fact, while the context of reform may have been the growth of human rights and developments in Northern Ireland, many of the specific reforms came as a direct response to the findings and recommendations of the Morris Tribunal. This tribunal had stressed that what had happened in the division in question was not due to a number of rotten apples in the barrel, nor could it be said to be an isolated event. ${ }^{93}$ It was reflective of weaknesses in management structures, which failed to prevent abuses from occurring. In spite of this, the Garda Síochána Act 2005 seems largely directed at attending to specific problems which arose in the Donegal division, from an individualised, rather than institutionalised perspective. Arguably, it could not be denied in Northern Ireland that problems were endemic and institutionalised, whereas in the Republic this was not the case. Reform of accountability structures has, both now and in 1986, been dominated by scandal - the Kerry Babies case in the 1980s and the Morris Tribunal in this decade - giving it a reactionary nature. The result is a system of accountability which when analysed in view of this framework, is found to be seriously weak and flawed.

While ostensibly the Garda Síochána Act 2005 implemented many worthwhile and much needed reforms, the fundamental problem highlighted here is the failure to take a considered approach to what accountability should mean for An Garda Síochána. In proposing the legislation, the Government did not question the purpose of a system of accountability. Opposition parties, NGOs, interest groups and other commentators, all keen to stress the positive aspects of Patten, neglected that which made the Patten Report so important - its attempt to develop a holistic system of accountability.

As a result, Ireland now has a greatly reformed system of police accountability in place but with very real deficiencies. Democratic accountability, while now appearing to be enhanced through JPCs, is, in fact, worryingly weak. There needs to be greater public involvement in policing, as well as a more developed sense that the public is entitled to question the force. This links to the point made that An Garda Síochána has not adopted the approach to transparency advocated by the Patten Commission. There has been no attempt to make a cultural shift towards openness in a meaningful way. Internal accountability has been largely neglected in recent reforms and, as the first line of defence with the greatest capacity to prevent abuses from occurring, this is regrettable. Legal accountability has perhaps received the most substantial attention, but in a limited sense. All focus has been on the Ombudsman Commission but, as Vaughan argues, in a holistic system it would play a "vital" role but it would be "much more minor than that envisaged in the debate on police accountability hitherto". ${ }^{94}$ No efforts have been made to address the inability of the criminal justice system to secure convictions against officers who have breached the law.

There remains potential for preventable abuses to occur within An Garda Síochána. This potential could have been substantially reduced had a coherent theoretical approach to reform been adopted. The Patten Commission offers one such approach. It could be of

93 Morris (2004) (n. 52 above), para. 6.05.

94 Vaughan, "A new system" (n. 5 above), p. 20. 
great use to other jurisdictions seeking to reform policing and police accountability, but, as the Irish experience shows, cherry-picking from the recommendations of the report will not suffice. The way in which the Patten Report was presented in this debate as a series of new institutions, rather than a framework for accountability, is indicative of the overarching approach to reforming this area more generally. What the Government provided through the Garda Síochána Act 2005 is a similar checklist system of institutions and regulations, with no foundations in theory. Had Ireland adopted the Northern Irish approach, there would have been greater emphasis on democratic accountability and transparency. There may even have been a cultural mind-shift among legislators as to the role of accountability not just as a reaction or a defence but as a way of enhancing police legitimacy and policing by consent. 